\title{
MODELLING PROBABILITY OF DEFAULT AND OPTIMAL PTI LEVEL BY USING A HOUSEHOLD SURVEY*
}

\author{
Tamás BALÁS - Ádám BANAI - Zsuzsanna HOSSZÚ \\ (Received: 26 August 2014; revision received: 4 December 2014; \\ accepted: 29 January 2015)
}

\begin{abstract}
The risks of household lending are still a major issue in Hungarian banking. The proportion of nonperforming loans is rising continuously. We constructed a model to find those factors which have significant effect on the probability of default of households' mortgages. We also used this model to calibrate the optimal level of household mortgages' payment-to-income ratios, which is important from a regulatory point of view. Our results show that the denomination of the loan and the indebtedness of the household are crucial factors in the performance of the loan. We also show that loans contracted via agents are riskier than others. The results carry two important messages from a regulatory perspective. Prescribing the same payment-to-income (PTI) ratios for HUF and FX loans may be unnecessarily restrictive for the former and excessively permissive for the latter. The uniform regulation of households with different income levels may also lead to undesired anomalies.
\end{abstract}

JEL classification indices: E58, G01, G21

Keywords: FX lending, probability of default, payment-to-income ratio, bank regulation

* We are grateful to the two anonymous reviewers for their valuable comments and suggestions.

Tamás Balás, Senior Economist at Magyar Nemzeti Bank (MNB, the central bank of Hungary). E-mail: balast@mnb.hu

Ádám Banai, Head of the Applied Research and Stress-Test Department at the Magyar Nemzeti Bank (MNB, the central bank of Hungary). E-mail: banaia@mnb.hu

Zsuzsanna Hosszú, corresponding author. Analyst at Magyar Nemzeti Bank (MNB, the central bank of Hungary). E-mail: hosszuzs@mnb.hu 


\section{INTRODUCTION}

The financial crisis starting in 2007 changed the environment of banking systems profoundly, and this did not leave the Hungarian financial intermediary system unscathed. The banking sector responded to the crisis by substantial balance sheet deleveraging, while non-performing portfolios rose to record heights. Despite government measures and banks' efforts, nearly a fifth of the entire household loan portfolio was non-performing at the end of 2013. ${ }^{1}$ This level is extremely high in regional comparison, even if one-off factors such as the early repayment scheme also increased it.

Relying on micro data, our research was primarily focused on exploring the macro, socio-demographic, and loan characteristic variables that account for the probability of default (PD) in the case of household mortgage loans. To that end, we applied binary estimation methods, mainly logit models, as modelling tools. A key task of our exercise was to examine the relationship between the paymentto-income ratio (PTI) and credit risks. In this framework, we attempted to identify the maximum PTI level at which the overindebtedness of households may be still avoided. The latter is not only important from the perspective of households, but may also be a crucial factor for financial stability considerations. Thus, besides serving ground-breaking analytical purposes, our research may provide a sufficient foundation for regulatory authorities to develop measures for preventing the build-up of macroprudential risks.

Our study is structured as follows: after the introduction, we provide an overview of the relevant Hungarian and international literature, primarily from the aspect of default. This is followed by the presentation of data used for the purposes of our study and, since a sampling technique is applied in our micro database analysis, we also assess the representativity of our sample (relative to macro data). The next section includes a detailed description of our model specification, the results gleaned from the estimation, and a robustness analysis. A separate section is devoted to variables that were excluded from our estimate despite their potential impact on the probability of default, as confirmed by empirical observations. We also offer an explanation for their exclusion. In the last part of our paper, we discuss the relationship between the payment-to-income ratio and credit risks before providing a summary of our most important conclusions.

1 The non-performing ratio remained very high (19.2\%) at the end of 2014. 


\section{RELEVANT LITERATURE}

The most important feature of Hungarian mortgage loans to households is its denomination structure, given that at the beginning of the crisis, $70 \%$ of the loan portfolio was denominated in foreign currency, especially in Swiss francs. The reasons for the emergence of foreign currency lending to households have been discussed extensively both in the Hungarian and in the international literature (e.g. Zettelmeyer et al. 2010; Bethlendi 2011; Király - Banai 2012; Hudecz 2013). Basso et al. (2007) established that, among other factors, an easy access to foreign currency financing, large interest rate differentials between domestic and foreign currencies, and the openness of economies all shifted households' focus to foreign currency borrowing. All these factors were prominently present in Hungary at the time. During the crisis, the HUF exchange rate depreciated considerably against the Swiss franc and, consequently, the performance of the substantial retail FX loan portfolio deteriorated substantially.

Hosszú (2011) concluded that the open exchange rate position of households played a role in the default of retail loans. The paper relies on the cross-sectional micro database of the Household Budget Survey (HBS) compiled by the Central Statistical Office (CSO) for the period of 2004-2008 for analysing the consumption patterns and borrowing decisions of households and the heterogeneity of these decisions in various income brackets. It draws conclusions based on the indebtedness and labour market position of households, identifying the macroeconomic factors that may have played an important role in the non-performance of certain income strata. According to this database, after the outbreak of the crisis, even a slight strengthening of the Swiss franc exchange rate may have resulted in debtrepayment problems in the low-income strata owing to high instalment amounts relative to income, whereas in the case of the medium-income strata, the increase in the ratio of non-performing loans may have been caused primarily by the loss of employment. The greatest disadvantage of the HBS survey compared to that used in this paper is that it offers far less information about the loans granted to households. ${ }^{2}$

Gáspár - Varga (2011) also used the HBS micro database for modelling the repayment problems. They assume that a household cannot perform its repayment obligation if its monthly instalment exceeds $40 \%$ of its net income (as the remaining $60 \%$ should cover basic consumption expenditures). The authors attributed

2 The HBS introduced the question set related to household loans only in 2010. At the same time, even the surveys compiled in subsequent years do not include data on restructuring or the exchange rate cap. Moreover, regarding the NPL ratio of the banking sector, the HBS data are not representative. 
the resulting default to three factors: the initial level of indebtedness (PTI) was already too high; depreciation of the HUF exchange rate; loss of employment. Based on their findings, high initial indebtedness and exchange rate changes were responsible for $50 \%$ and $45 \%$ of defaults, respectively, while unemployment accounted for the remaining, almost negligible percentage. Once again, the use of the HBS implied a disadvantage due to its restricted and non-representative information base on loans (for instance, based on HBS data, the household loan portfolio is far smaller than the actual outstanding debt of the sector).

Holló (2009) used the panel database of three commercial banks with substantial households' exposure. The applied method in this case was survival analysis, which takes into account that the probability of default is varied in different life cycles of the loan. His findings suggest that the loans' denomination structure, the initial loan-to-value (LTV) ratio, and the debtor's level of education can be considered as the main customer- and product-specific drivers of default risk, while the unemployment rate, domestic and foreign interest rates as well as the exchange rate constitute the major macro-risk factors impacting defaults. ${ }^{3}$

Holló - Papp (2007) is another noteworthy study in the Hungarian literature. The authors set out to model the probability of default by using financial margin calculations, logit, and neural network approaches. According to their findings, disposable income, the number of dependants, the share of monthly debt servicing costs, and the employment status of the head of the household have meaningful explanatory power. The resultant models were used to test the shock-absorbing capacity of the banking system. Although this is the earliest among those quoted and hence its conclusions are the farthest from those presented in this analysis, this was the MNB's last household survey comparable to this one. The most important difference between the two surveys lies in the scopes of questions asked since those have been extended in this study. The 2013 survey introduced questions about the value of all real estate owned by the household, not only those used as collaterals. Similarly, questions were included in this survey about a possible restructuring and its date, participation in the exchange rate cap and the early repayment scheme, and the involvement of a lending intermediary.

The results of the relevant Hungarian literature, so far, can be summed up as follows: both Hosszú (2011) and Gáspár - Varga (2011) attribute the default of household loans to three main factors: initial debt overhang, loss of employment, and the change in the monthly instalment amount. The former merely attempted to explain which factor affected which income bracket the most, while the latter

3 Ultimately, the model received was used for stress testing purposes. Its enhanced version is still used in the MNB's solvency stress tests in order to calculate households' default probabilities (the actual model is described in Banai et al. 2013). 
decomposed and quantified the role of each element in households' non-performance. Since, according to the former paper, excessive indebtedness was most typical in the low income brackets, and the latter pointed out that debt overhang was the most important factor leading to default, low-income households are presumably over-represented within defaulting households. Similarly, the estimates of Holló - Papp (2007) and Holló (2009) reconfirm that all three factors (debt overhang, unemployment, and instalment increases) play a role in changes in the probability of default: debt overhang is measured (directly or indirectly) by the LTV, households' disposable income, the payment-to-income ratio, and the number of dependants. The customer's level of education and the labour market position of the head of the household are indicators of the probability of unemployment.

Our analysis goes beyond the limits of previous Hungarian studies in several respects. On the one hand, it distinguishes between various product types and provides information about the features of loans disbursed in different years. On the other hand, based on the model, it draws relevant conclusions from a regulatory perspective as well.

The performance of household loans is also a common topic in the foreign literature. Blanco - Gimeno (2012) - based on the data of the Spanish credit register has shown that the dynamics of non-performing loans was explained mostly by unemployment, credit stock, and a composite measure on instalment burden and revenue. Lydon - McCarthy (2013) examined the Irish mortgage market. Their results were intuitive since default was explained best by debt service burden and LTV. In addition, labour market position and the purpose of the mortgage (i.e. investment or self-use) were also significant explanatory variables. Mian - Sufi (2011) focused on the mortgage crisis of the US. They found that the probability of default increased most in those places where the swing in house prices was the biggest. In other words, the changing value of the collateral behind the loan influences significantly the probability of repayment.

There are also some examples where default probability was estimated from household surveys, by using binary choice models. May - Tudela (2005) estimated a dynamic probit model for the probability of British households. The same households were interviewed each year; therefore, they had an opportunity to look at the impact of individual factors dynamically. They found that of all the variables under review, becoming unemployed had the largest marginal effect upon the probability of mortgage payment problems. In addition, interest income gearing also had a pronounced effect (interest payments and principal payments relative to income were examined separately). According to the authors, having unsecured debt and this being a heavy burden on the household significantly increased the probability of having mortgage payment problems. Overall, the ability to repay was equally determined by labour market position and the size of the 
instalment amount (which depends on indebtedness); in other words, the findings were consistent with those found on Hungarian data.

Finally, La Cava - Simon (2003) drew on data from a household survey to explore variables influencing the performance of loans. For our purposes, it is of special importance that the sample used for the logit model estimated by the authors included, similarly to ours, cross-sectional information only. The study was not focused exclusively on the performance of loans, but on the financial difficulties households faced in general. The authors wanted to find out which characteristics increased the probability of a household being financially constrained during the time of their review (at the turn of 1998/99). According to their analysis, a broad range of variables proved to be significant. Besides such variables as unemployment, the size of mortgage repayment, interest payable on credit card debt and income, certain one-off debtor characteristics such as age or household size also had a significant explanatory power. In sum, the international literature reveals that binary variable models have been used on several occasions to assess the financial performance of households. In these models, income and labour market position and the level of indebtedness had significant explanatory power in the assessment of households' performance.

\section{THE DATA}

In August 2013, the central bank of Hungary (MNB) collected information about indebted households via a questionnaire-based survey. The purpose of the survey was to enable the MNB to gain in-depth information about the financial position, level of indebtedness, and saving habits of households. The survey prepared with the assistance of GfK Hungária Market Research Institute involved households where at least one family member had some kind of a loan. The 1,000 households interviewed had a total of 1,322 loan contracts. Of all loan contracts, housing loans had the largest share in terms of number, with 341 such loans in the sample. Personal loans (196), overdrafts (176), home equity loans (163), and vehicle loans (138) also had a significant share. The number of student loans (28) and card-based credits (83) was relatively low. The ratio of product types to the total portfolio is nearly identical with the data seen in the banking sector.

It was an important objective of the survey to be representative in several regards: on the one hand, it had to represent households with outstanding loans according to a few important socio-demographical characteristics (such as household composition or the settlement type of the household's residence). On the other hand, the survey had to ensure that the value of specific products in proportion to the total portfolio should correspond to that seen in the banking sector. Since 
we have no information on the distribution of indebted households according to social attributes, the results of the survey can only be compared to the distribution of all households. Although this comparison may therefore show some differences, it can still be used as a point of reference. For example, 201 respondents of the 1,000 interviewed were reported to live in Budapest, which roughly corresponds to the ratio of Budapest citizens to the total population, i.e. $18 \% .251$ respondents were reported to live in a county seat, which slightly exceeded the actual $20 \%$ ratio. The $37 \%$ ratio of other towns is also somewhat higher than the actual $30 \%$ national ratio. Thus, taken together, the ratio received for debtors living in smaller municipalities was smaller than the $30 \%$ ratio to total households.

The denomination of loans outstanding is a key question in the case of household loans, given that one of the most important risks of the portfolio stems from this feature. With that in mind, we examined the extent to which the currency composition received during the survey corresponded to banking sector data. With one exception, we did not find any significant differences. It was only in the case of housing loans that CHF- and JPY-denominated loans comprised a larger part of the sample than in reality. Consequently, HUF loans were under-represented. In the case of other product categories, we did not discern any significant differences and we can state that, overall, our sample is adequate even from the aspect of currency composition.

Table 1

Distribution of selected credit products by their denomination, 2013

\begin{tabular}{|l|c|c|c|c|c|c|c|c|c|}
\hline \multicolumn{9}{|c|}{ Survey (\%) } & \multicolumn{5}{c|}{ Banking system - actual (\%) } \\
\hline $\begin{array}{l}\text { Denomi- } \\
\text { nation }\end{array}$ & $\begin{array}{c}\text { Housing } \\
\text { loans }\end{array}$ & $\begin{array}{c}\text { Home } \\
\text { equity } \\
\text { loans* }\end{array}$ & $\begin{array}{l}\text { Vehicle } \\
\text { loans }\end{array}$ & $\begin{array}{c}\text { Personal } \\
\text { loans }\end{array}$ & $\begin{array}{l}\text { Denomi- } \\
\text { nation }\end{array}$ & $\begin{array}{c}\text { Housing } \\
\text { loans }\end{array}$ & $\begin{array}{c}\text { Home } \\
\text { equity } \\
\text { loans* }\end{array}$ & $\begin{array}{c}\text { Vehicle } \\
\text { loans }\end{array}$ & $\begin{array}{c}\text { Personal } \\
\text { loans }\end{array}$ \\
\hline HUF & 30 & 11 & 26 & 87 & HUF & 45 & 18 & 32 & 81 \\
\hline EUR & 7 & 11 & 3 & 1 & EUR & 7 & 9 & 2 & 2 \\
\hline CHF & 60 & 78 & 70 & 12 & $\begin{array}{l}\text { CHF and } \\
\text { others }\end{array}$ & 48 & 73 & 66 & 17 \\
\hline JPY & 3 & 0 & 0 & 0 & & & &
\end{tabular}

Source: MNB and our survey.

* General purpose loans collaterised with real estate.

Finally, we compared our sample to the banking sector data in respect of delinquency as well. This is a particularly important aspect, as the primary goal of our analysis is to explore the reasons for the non-performance of household loans. Regarding delinquency, we were focusing only on mortgage loans since our analysis was dealing only with their performance. Loans overdue more than 90 days deserve special attention because they are considered non-performing 
loans. Based on this definition, of all products under review, banking sector data and data from the survey were nearly the same. The difference between them amounted to 1 percentage point and 2 percentage points, respectively.

Table 2

Distribution of various credit products

\begin{tabular}{|l|c|c|c|c|}
\hline \multirow{2}{*}{$\begin{array}{c}\text { Delinquency } \\
(\%)\end{array}$} & \multicolumn{2}{|c|}{ Survey } & \multicolumn{2}{c|}{ Banking system - actual } \\
\cline { 2 - 5 } & Housing loans & $\begin{array}{c}\text { Home equity } \\
\text { loans* }\end{array}$ & Housing loans & $\begin{array}{c}\text { Home equity } \\
\text { loans* }\end{array}$ \\
\hline Performing & 67 & 51 & 75 & 53 \\
\hline Less than 1 month & 8 & 6 & 9 & 12 \\
\hline Between 1-3 months & 10 & 13 & 4 & 7 \\
\hline More than 3 months & 14 & 30 & 13 & 28 \\
\hline
\end{tabular}

Source: MNB and the survey.

* General purpose loans collaterised with real estate.

\section{MODELLING OF DEFAULT PROBABILITY ${ }^{4}$}

\subsection{Structure of the model}

As the data of the survey are representative, they are suitable both for analysing household loans and for modelling purposes, although it is important to add that due to the early repayment scheme in 2011, the portfolio quality in the banking system (as of mid-2014) was somewhat worse than the originally issued portfolio, because most of the households using the early repayment scheme were better performing debtors. With our estimates we intended to find out which factors play a relevant role in the default probability of mortgage loans, and we also quantified the effect of each variable. We did not focus on the relation between any specific variable and the probability of default. Our goal was constructing a model which can reliably estimate the probability of default.

The data structure enabled us to estimate cross-sectional, binary choice models. We chose the survey question pertaining to repayment delinquency as our response variable; if the instalment of the specific loan is 90 days past due, our dependent variable will take the value of one, otherwise it will be zero. A delinquency of over 90 days is customarily considered in the literature as a non-performing contract,

4 List of all tried variables in the estimation, correlation between variables, estimation results, model's goodness-of-fit statistics is available in an MNB occasional paper (Balás et al. 2015) or can be obtained from the authors. 
and we followed the same practice. Having said that, due to the limitations of the data available, our interpretation of the probability of default (PD) differs somewhat from the usual concept in respect of time horizon. The estimated or projected PD values usually refer to becoming non-performing within a year. Since the database we relied on does not contain specific information about when exactly the debtor fell 90+ days delinquent and we performed the estimate in a cross-sectional structure, instead of PD within a year, our estimated PD values capture the probability of default from the disbursement of the loan to the date of sampling. Consequently, below we will refer to this value as long-term PD. The disadvantage of this definition is that the time elapsed since the issuance of these loans differs significantly in some cases (the oldest contract was made in 1978 and the youngest one in 2013). It is a general observation about mortgage loans that, from the perspective of becoming delinquent, the first 5 years of the term are critical. Indeed, loans which remain performing during the first 5 years are highly unlikely to fall delinquent later.

$20 \%$ of the sample consists of contracts dated after 2008, and since not even the riskiest first five years have passed since then, the ratio of non-performing loans within this group may be smaller (with all else being equal) for this reason alone. Similarly, the observed default rate may be significantly lower than the actual value in the case of loans older than 10 years, given that for some customers who defaulted at the beginning of the loan's maturity, even the post-default stage may have ended already. However, the exclusion of the pre-2004 and post2008 parts of the sample would entail the loss of valuable information: we would be forced to exclude $35 \%$ of observations, including $69 \%$ of HUF loans. Based on these considerations, we decided to use the entire sample as long as there are no major differences between estimates received for the sample limited to the 2004-2008 period and for the total sample.

Since the sample included some households with more than one mortgage loan, we could have performed estimates either on contract-level or on household-level data. We decided to do the former for two reasons: on the one hand, contract-level data produced a larger sample size; on the other hand, we found some examples where one of the household's loans had become 90 days past due already, while there were no payment problems with the other loan. This situation could not have been addressed properly if household-level data had been used.

$$
\begin{aligned}
& y(0=\text { performing }, 1=\text { defaul }) \\
& =G\left(\beta_{0}+\beta_{1} * \text { indebtedness }+\beta_{2} * \text { income }+\beta_{3} * \text { labour market activity }+\beta_{4}\right) \\
& * \text { household expenditure }+\beta_{5} * \text { loan characteristics dummy }+\beta_{6} \\
& \text { * household characteristics dummy } \\
& \text { where } G(x)=\frac{e^{x}}{1+e^{x}} \text {. }
\end{aligned}
$$


We defined six variable groups, which might have significant effect on the probability of default: indebtedness of the household, income position of the household, labour market activity of the household, spending (not instalments) of the household, characteristics of the loan contract, and social characteristics of the household. There are several opportunities to measure these factors. For example, different ratios can grab the labour market position of the household. In many cases, these variables contain the same information (on PDs), but sometimes variables representing the same group can have relevant additional information compared to each other. We will therefore use the following strategy: we will keep the most significant variable of each group, but other significant variables from the same group can be kept as well. Regarding the six-variable group in the case of "indebtedness", our expectation was unambiguously of a positive sign, i.e. higher indebtedness results in a higher probability of default. Instalment (starting, actual, PTI, and per capita), LTV, loan size, and instalment of other loans were tried in this variable group. Income of the household also should be important since higher income has to result in a lower default probability, ceteris paribus. This factor was taken into consideration by two variables, namely income of the household and income per capita. Our expectation for the labour market activity of the household was similar to that in case of income. An improving situation on the labour market - measured by the proportion of income earners active on the labour market - decreases the probability of default. Rising expenditures decrease the amount that can be used for debt servicing, which will result in a higher probability of default. Characteristics of households and loan contracts can vary significantly, so the expected signs are unambiguous. The most important loan characteristics were denomination (probability of default is expected to be higher for FX), loan type (home equity loans perform worse), date of issuance (loans of 2007-08 are riskier), LTV above 100 per cent (higher risks), and contracts via agents (higher PD is expected). Finally, the following household characteristics were considered: higher level of education may result in lower PD; higher PD was expected in the case of smaller settlement types; finally, households with savings were expected to be less risky.

The final version of the model presented here includes only the explanatory variables that proved to be significant at the $5 \%$ level. Of the binary variable estimation procedures, we chose the logit estimate, and in order to validate the robustness of the method, we also applied a linear probability model to the explanatory variables received. Based on the correlation between explanatory variables in the model, the existence of extreme multicollinearity can be rejected. 


\subsection{Partial effects}

Ultimately, of all the listed variables, seven explanatory variables proved to be significant (in addition to the constant variable). Since (contrary to the linear probability model) partial effects differ for each observation in the case of logit estimates, we indicated the average partial effects customarily used in the literature. On the basis of Hosmer-Lemeshow test, we cannot rule out the model's goodness of fit at either customary significance level.

Looking at the characteristics of households among the variables that proved to be significant, the "ratio of income earners to household members" measures the composition of households according to labour market activity and income position. According to the estimate, more income earners within the same household reduce the probability of default proportionately. This can be quantified as follows: if, ceteris paribus, the number of income earners increase from 2 to 3 within a 4-member household, long-term PD will decline by 8.14 percentage points (on average, half of the members of a household have income).

The PTI ratio measures the burden incurred by the household in repaying the loan amount, the level of indebtedness. In this context, it should be noted that although the questions of the survey included one pertaining to the household's income, in many cases no appreciable responses were received. At the same time, a detailed set of questions referred to households' expenditures and savings, the net result of which (including, in theory, monthly instalments) captures income. Since the level of completion of these parts was higher, we used this artificial

\section{Table 3}

Partial effects and significance levels of the estimated model's variables

\begin{tabular}{|l|c|c|c|}
\hline \multirow{2}{*}{ Variable } & \multicolumn{3}{c|}{ Average parcial effect (percentage point) } \\
\cline { 2 - 4 } & Logit & Logit 2004-2008 & Linear \\
\hline Constant & $-1924^{* * *}$ & $-29.28^{* * *}$ & -2.19 \\
\hline $\begin{array}{l}\text { Ratio of income earners to household } \\
\text { members }\end{array}$ & $-8.14^{* * *}$ & $-8.53^{* * *}$ & $-7.85^{* * *}$ \\
\hline Payment-to-income (PTI) & $0.76^{* * *}$ & $0.89^{* * *}$ & $1.26^{* * *}$ \\
\hline FX-denominated & $5.70^{* *}$ & $7.90^{*}$ & 2.96 \\
\hline Payment-to-income belonging to other loans & $0.24^{* * *}$ & $0.28^{* * *}$ & $0.24^{* * *}$ \\
\hline Instalment per income earner & $305^{* * *}$ & $-3.45^{* * *}$ & $-3.97^{* * *}$ \\
\hline Non-instalment expenditures & $0.21^{* *}$ & $0.25^{* * *}$ & $0.33^{* * *}$ \\
\hline Loan via agents & $5.46^{* * *}$ & $7.53^{* * *}$ & $5.63^{* *}$ \\
\hline
\end{tabular}

Note: $*$ indicates variables significant at $10 \%, * *$ and $* * *$ indicate $5 \%$ and $1 \%$ significance, respectively. 
variable to approximate the income of the household concerned. Moreover, for the purposes of our estimate, we used the household's actual PTI as of August 2013 (in the lack of income data, the initial PTI value was not available). Based on the results, the greater a household's debt in proportion to its income, the higher the long-term PD of its loan; i.e. a 1 percentage point increase in PTI will increase the long-term PD by 0.76 percentage points on average (with all else being equal). According to the estimate, the risk associated with a loan will be greater if the household has debt service on other loans as well. This effect is captured by the variable "payment-to-income ratio for other loans". The average partial effect of this variable ( 0.24 percentage points) is smaller than that of the other PTI variable. This may be due to the fact that other loans also include unsecured loans, and if a household fails to pay the debt service on its secured loan and on its unsecured loan at the same time, it will be inclined to fall delinquent with the unsecured loan. Consequently, indebtedness with unsecured loans deteriorates the payment discipline observed in the case of secured loans to a lesser degree. The ability to repay is not only influenced by instalment-type expenditures. Households with higher other (non-instalment) expenditures (e.g. food, housing, durable and semi-durable goods, etc.) also face a higher probability of default. A HUF 10,000 difference in expenditures will raise the value of longterm PD, ceteris paribus, by 0.21 percentage points on average.

The results presented so far are completely consistent with economic intuition in terms of their positive or negative sign. By contrast, it might be surprising that the variable "instalment per income earner" has a negative sign; in other words, a higher instalment amount will induce a lower PD value. This variable, however, does not capture the indebtedness of the household: according to the definition of the partial effect, an increase in the instalment amount, ceteris paribus, reduces long-term PD. Since the rest of the variables include PTI, all else can only be equal if the higher instalment amount is coupled with higher income. Therefore, instead of indebtedness, this variable is much more likely to capture income position or, instead of the instalment amount, it measures the instalment amount that a household is capable of paying. ${ }^{5}$ In consideration of this, the negative sign of the partial effect is understandable. To confirm this view, we also estimated our model excluding the PTI variable. This way, the partial effect of the instalment per income earner became positive, i.e. it grabs the indebtedness now.

In respect of the features of the loan, two variables proved to be significant in the estimate. Firstly, foreign currency loans are riskier than HUF-denominated

5 As has been mentioned, we could only approximate the household's income position by means of an artificial income variable; it must have been due to the lack of an actual income variable that "instalment per income earner" gained such a meaning. 
loans (owing to exchange rate driven instalment increases); specifically, foreign currency denomination raises long-term PD by 5.7 percentage points on average. In addition to the depreciation of the exchange rate, it might be the result of a unilateral increase of interest rates by banks, which was very common in the case of FX loans. It also raised the debt service burden of loans. Secondly, compared to directly disbursed bank loans, the default probability of loans via agents, ceteris paribus, is $5.46 \%$ higher on average. Probably, riskiness of loans via agents can stem from the fact that agents' relation with their customers is usually shorter and smaller than that of bank officials. Their motivational methods are also different. Therefore, the asymmetric information problem is bigger than in the case of other contracts.

\subsection{Robustness analysis}

As we have mentioned before, in order to exclude the possible distortions stemming from the different years of disbursement, we have also applied the estimation on a more restricted, relatively homogeneous sample (2004-2008). The partial effects are completely consistent with each other on both samples in terms of their signs, and the same is true for the set of variables significant at the $10 \%$ level ${ }^{6}$. Except for the foreign currency dummy, the two models select the same variables even at the 5\% significance level. In absolute value, the degree of average partial effects is somewhat higher for all variables in the reduced sample, but more noteworthy differences can be observed in the case of the two dummy variables. In the case of the FX dummy this was to be expected in any event, given that the instalment increases stemming from the volatility of the exchange rate were significantly higher for loans disbursed during this period than for those disbursed later. (The estimation of FX dummy on the shorter sample is more uncertain since the proportion of HUF loans was much smaller during that period). The level of these differences, however, did not warrant, in our opinion, the restriction of the sample. (We have also examined the difference between loans with different disbursement years by using another approach, which is discussed later in the study, but we could not identify any significant effect in that case either.)

In order to validate the robustness of the results from the aspect of the estimation procedure, we prepared an estimate with a linear probability model as well, which included the variables found significant by the logit models. Except for the FX dummy, the linear model also found all variables significant at the 5\% level.

To calculate the levels of significance, we applied White's heteroscedasticity-consistent robust standard errors. 
Partial effects are completely identical in terms of their signs; as regards their magnitude, they exhibit more substantial differences in two cases: in the case of the FX dummy and the PTI. In the first case, the linear model has a lower value; in the second case, the model estimates a higher partial effect. Since the PTI in the estimate pertains to the time of the survey rather than the situation as at loan disbursement (on which no information is available), the effect of the exchange rate depreciation is reflected in the PTI as well. Thus the PTI of FX loans is higher in the sample than that of HUF loans. This may account for the difference observed between the partial effects of the two models; in other words, in the case of FX loans the risk stemming from exchange rate changes is mainly reflected in the FX dummy in the logit model, and in the PTI in the linear model. Therefore, the results of the model proved to be robust from this aspect as well.

\section{EXCLUDED VARIABLES}

\subsection{Housing loan vs. home equity loan}

Several variables that should have a good explanatory power based on observations are excluded from the model. The dummy variable pertaining to the different product types did not prove to be significant, although, based on the statistics on non-performing loans, there is a significant difference in terms of the performance of the two product categories. While the share of non-performing loans within the housing loan portfolio was below $15 \%$ at the end of 2013 , this rate approached $30 \%$ in the case of home equity loans. This difference is only partly explained by the fact that there are hardly any HUF-denominated loans among home equity loans, while HUF loans have a substantial share in housing loans. If we only look at FX-denominated home equity loans, the difference between NPL ratios is still significant: the share of NPLs in the total portfolio is $18 \%$ for housing loans and close to $30 \%$ for home equity loans.

The above difference indicates that product type may have a significant impact on the probability of default. We examined why, in spite of this, the product dummy had no significant explanatory power in our model. We identified the factors which may influence the probability of default yet are markedly different in the case of the two different products. The first such factor is the currency mismatch mentioned above (only $54 \%$ of all housing loans are denominated in foreign currency, while this ratio is above $80 \%$ in the case of home equity loans). This, however, does not explain the difference in the performance of foreign currency denominated loans for these two products. Looking at these two products separately, we find additional factors exhibiting significant differences that in- 
Table 4

Selected features of home equity loans and housing loans

\begin{tabular}{|c|c|c|c|c|c|c|c|c|}
\hline \multirow[b]{2}{*}{ per cent } & \multirow[b]{2}{*}{$\frac{a}{2}$} & \multirow[b]{2}{*}{$\frac{\mathfrak{d}}{\vec{b}}$} & \multicolumn{6}{|c|}{ Characteristics of the household } \\
\hline & & & 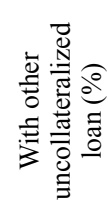 & 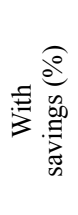 & 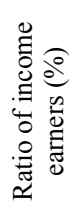 & 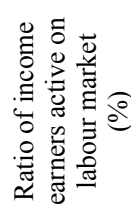 & 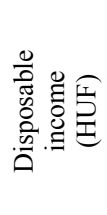 & 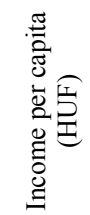 \\
\hline Housing loans & 61 & 27 & 29 & 12 & 61 & 54 & 245,482 & 76,219 \\
\hline $\begin{array}{l}\text { Home equity } \\
\text { loans* }\end{array}$ & 78 & 33 & 33 & 5 & 61 & 46 & 225,459 & 68,607 \\
\hline $\begin{array}{l}\text { Housing loans } \\
\text { (FX) }\end{array}$ & 82 & 33 & 31 & 12 & 62 & 54 & 260,858 & 79,410 \\
\hline $\begin{array}{l}\text { Home equity } \\
\text { loans (FX)* }\end{array}$ & 92 & 37 & 36 & 3 & 63 & 46 & 230,482 & 69,884 \\
\hline
\end{tabular}

Source: The survey.

Note: HUF/EUR exchange rate, as of the end of 2013: 242.

* General purpose loans collaterised with real estate.

crease the probability of default, and we consider them, in some way, in our model. The first such variable is average PTI. The PTI value of housing loans is $27 \%$, while the same ratio was $33 \%$ for home equity loans. A higher PTI value increases the probability of default. The risk of debtors with home equity loans was also increased by having other, unsecured loans, which, in their case, was more typical. Being an additional burden, this reduced their ability to repay in and of itself. In addition, it is also important to consider that having the rescue package for foreign currency debtors on the agenda reduced debtors' willingness to repay even further if they also had other loans, as the suspension of instalments may have enabled them to repay their unsecured loans. The evolution of the average LTV (loan-to-value) ratio is another important characteristic of individual loan categories. Although this variable has not been included in the model directly, this effect is partly reflected through the instalment amount. In the case of home equity loans, the average LTV value of the portfolio is 17 percentage points higher than that recorded for housing loans, i.e. the size of the loans was bigger relative to the collateral. While a higher LTV ratio is less of a decisive factor in Hungary for willingness to repay, it is still considered to increase risk. In addition, borrowers' heterogeneous savings position also implies a difference. $12 \%$ of housing loan borrowers have financial savings, compared to $5 \%$ of home equity loan borrowers.

There is a difference between the two loan categories in terms of the borrowers' labour market position as well. Although the ratio of income earners does not 
differ for indebted households across individual products, the ratio of active earners is higher for those with housing loans. An explanation for the difference in PTI is that disposable income is significantly higher for housing loan borrowers than for home equity loan borrowers. A similar difference can be observed in respect of per capita income. Per capita income is substantially higher for borrowers with housing loans. In conclusion, home equity loan borrowers were, overall, riskier customers based on their labour market position and the relative size of their loans. Accordingly, these factors are included in our model as significant explanatory variables for non-performance.

\section{2. "Vintage" effect}

Besides product type, the date of disbursement should also have a significant explanatory power based on intuitions. On the one hand, thanks to banks' high risk tolerance - as well as consumer behaviour - a much broader range of households had access to loans during the time of the upsurge in FX lending and the build-up of the FX-denominated mortgage portfolio (2004-2008) than in the years preceding or following this period. Thus, foreign currency denomination was not the only reason for the higher rate of loans' non-performance during this period. On the other hand, some analyses on domestic retail lending pointed out that even within this period, there was a difference in terms of the average performance of loans: directly preceding the crisis, during the period between 2007 and 2008, banks tended to grant loans to increasingly risky customers, deteriorating the quality of the portfolio progressively. This is demonstrated by the chart published in the November 2011 issue of the Report on Financial Stability (MNB 2011) analysing the performance of loans issued in different years. While non-performing loans within loans disbursed in 2006 reached the $7.5 \%$ ratio after 5 years, this ratio was $11 \%$ after 4 years already in the case of loans disbursed in 2007, and in the case of those issued in 2008, non-performing loans reached this $11 \%$ after 3 years. This demonstrates that loans to households have indeed become increasingly risky.

Despite all this, the dummy variable representing the different periods did not prove to be significant in the model prepared by us; therefore, it is worth examining the characteristics of loans issued during the different periods. Although the survey included loans disbursed before 2004 and after 2008 as well, we examined the "vintage" effect during the most intense period of household lending, the period between 2004 and 2008. We even split this period into two: one just preceding the crisis, the 2007-2008 period, and the period of the start of the surge: 2004-2006. We examined the strength of the vintage effect for these two periods by inserting dummy variables into the total sample (one that took the value of 
one in the case of disbursement in 2004-2006 and one for disbursement in the period of 2007-2008) and also by considering the restricted sample for the period of 2004-2008 only (and applied dummies for the period of 2007-2008 only), but we found that the variable(s) were not significant in either case.

Also, in this case, we examined the main characteristics of the contracts concluded in the specific periods for the product breakdown. The first significant difference is that average loan size increased by more than HUF 1 million during the period immediately preceding the crisis compared to the previous period. There is no significant difference in maturities between the two periods; however, the slight increase observed in this case points to increased lending risks. Denomination was a possible explanation not only for the performance difference between the different products, but also for that between different vintages. It is clear that the share of foreign currency loans increased further within loans disbursed in the period of 2007-2008, considerably exceeding the already high $72 \%$ characterising the 2004-2006 period. We could see that the size of loans in the second period exceeded substantially the value characterising the first period. This information, in and of itself, merely suggests that the risk associated with the loans increased. The LTV and PTI data confirm this assumption. Both the average PTI and the average LTV values were significantly higher in the second period than in the first one. Finally, we also examined how typical it was to take out other, unsecured

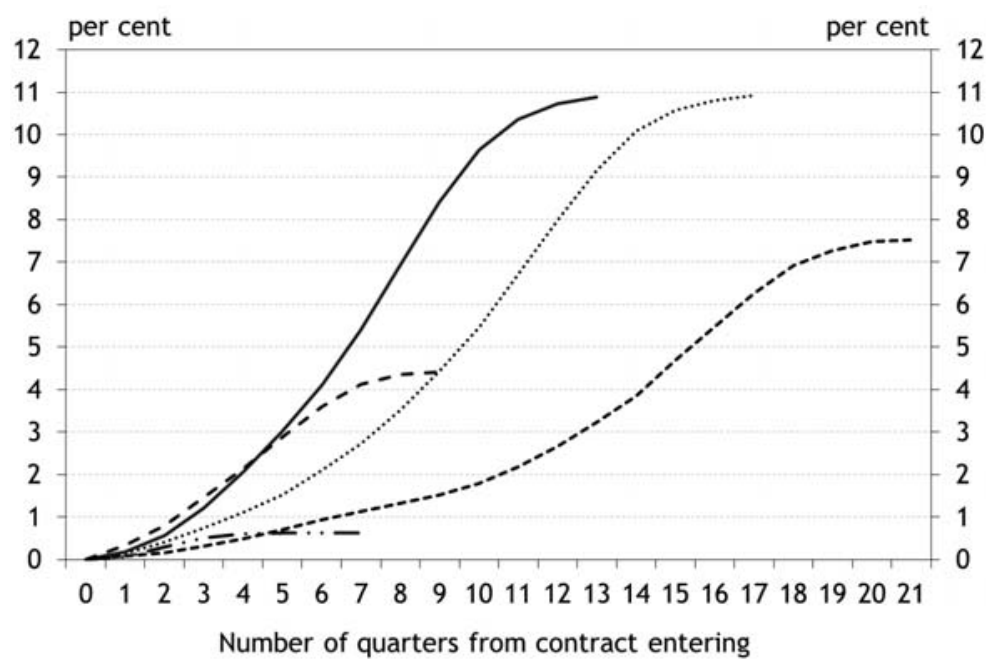

$$
\text { ---2006 …...2007 -2008 - - } 2009-\cdots 2010
$$

Chart 1. NPL ratio of FX-denominated mortgage loans disbursed in different periods Source: MNB. 
Table 5

Selected features of loans disbursed in the two reviewed periods

\begin{tabular}{|c|c|c|c|c|c|c|c|c|c|c|}
\hline & 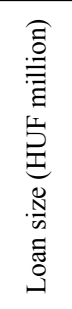 & 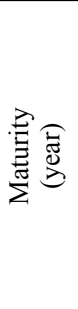 & 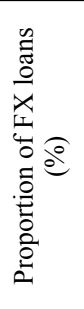 & $\vec{a} \stackrel{\varrho}{\varrho}$ & 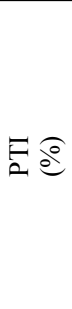 & 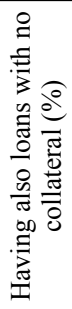 & 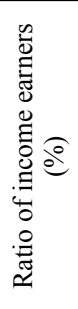 & 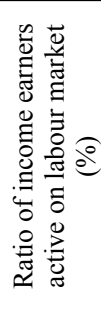 & 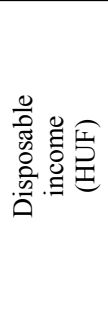 & 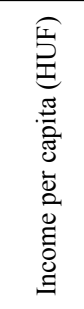 \\
\hline 2004-2006 & 4.23 & 18 & 72 & 64 & 27 & 30 & 56 & 47 & 241,693 & 71,966 \\
\hline $2007-2008$ & 5.51 & 20 & 84 & 88 & 36 & 33 & 62 & 52 & 240,146 & 69,964 \\
\hline
\end{tabular}

Source: The survey.

Note: HUF/EUR exchange rate, as of the end of 2013: 242.

loans in these two groups. While there is no material difference between the two figures, the second period performs slightly worse in this case.

We examined whether there was a difference in the labour market situation of borrowers in the case of loans disbursed during the two different periods. In this regard, a relatively small difference was observed between the two groups, and the direction of the differences is not straightforward. While the ratio of active employees within the family is slightly higher among the borrowers of the second period, disposable income is smaller, both as an absolute number and as a per capita figure. The difference, however, is very low in both cases. Thus, labour market position may not be considered significantly different in the two groups. Finally, we have to add that the initial exchange rate may also be a difference between the two periods. Especially in 2008, the HUF was very strong. While the average HUF/CHF exchange rate for the period 2004-06 was 163, for 2007-08 it was lower, around 155 . This factor may have some influence on the difference between the performances of the two periods.

We can see, overall, that it was not the different labour market situation that meant the main difference between the loans of these two periods, but the borrower's level of indebtedness after the disbursement of the loan, which supports the findings of Gáspár - Varga (2011). However, as the other variables integrated into the model (foreign currency dummy, PTI) to capture the explored differences, it is understandable that the vintage dummy cannot be significant. 


\subsection{Other excluded variables}

The exclusion of the two variables described so far required the most detailed presentation; however, we included some other variables in the database and tested their effects during the modelling exercise, but they did not prove to be significant. It is noteworthy to take account of them and explore the possible reasons for their exclusion. One of the most frequently used indicators capturing credit risk is the LTV ratio. The LTV expresses the size of the loan which also refers, implicitly, to the size of the instalment. And a high instalment amount increases the probability of default. In addition, a high LTV can also have a negative impact on willingness to repay; indeed, if the loan is worth more than the real estate collateral, it may be worth letting it default. In view of this, we tried to consider the possible effects of the LTV in two ways: as a continuous variable, the LTV itself was also included in the model; in addition, we introduced a dummy variable which took the value of one when the LTV rose above 100\% (i.e. when the collateral is worth less than the borrower's debt), otherwise it was zero. Behind the latter is the consideration that the deterioration of the willingness to repay is not necessarily in a linear relationship with changes in the LTV; it is more like a psychological threshold (with the obvious value of $100 \%$ ) that, once it is reached, may deteriorate drastically. The effect stemming from the relatively high instalment amount is not relevant in our model because this impact mechanism is captured by the PTI variable far more clearly and unambiguously. The second problem, in our case, is also irrelevant as, on the one hand, there is no private bankruptcy in Hungary and, on the other hand, borrowers principally used their own residential property as collateral for the loans. The ratio of mortgage loans where the loan's collateral was not the residential property was only $2 \%$ in the sample. Thus, choosing default is not a real option for borrowers.

Education often has significant explanatory power in respect of the default probability of loans. Nevertheless, this variable did not prove to be significant in our model (the reference category was elementary school education at the most; higher education levels were included in the model in the form of three dummy variables). This is because the education level, in reality, captures better labour market position and better income conditions. These factors, however, are already included, firstly in the share of income earners within the household, secondly by the PTI, and thirdly, by the per capita instalment amount. It can be explained by a similar logic that the dummy variables expressing settlement types (county seat, town with county rights, other towns, and smaller municipalities - with Budapest being the reference category) did not prove to have a significant explanatory power. 
Finally, participation in the exchange rate cap scheme was also excluded from the explanatory variables. This may have been insignificant because the exchange rate cap has a relatively short history in Hungary. Indeed, at the time of taking the survey, the scheme was hardly one year old. Usually, the restructuring of loans takes place because of some payment problem; however, despite the restructuring, such loans are more likely to become non-performing again than problemfree loans. Therefore, we also included a dummy for restructuring in the model, which eventually did not prove to be significant. This may be because loans subject to restructuring had been riskier to begin with, but this risk is already captured by the variables included in the model, thus the mere fact of restructuring does not carry any additional information.

\section{RELATIONSHIP BETWEEN THE PAYMENT-TO-INCOME RATIO AND CREDIT RISK}

Of the explanatory variables of the model presented above it is important to examine the payment-to-income ratio separately. PTI is used by the regulatory authorities of banks in several countries (including Hungary). Regulations pertaining to the PTI typically prescribe a limit which must not be exceeded by the PTI of disbursed loans. This, on the one hand, is designed to prevent borrowers from taking excessive burdens and, on the other hand, to limit, at least in part, the credit risks taken by the banking sector. At the same time, a PTI limit that is lower than justified restricts unnecessarily households' access to loans and, hence, impairs the efficient functioning and growth of the economy. At the beginning of the 2000s, several countries introduced PTI regulations in order to curb excessive credit expansion and prevent the build-up of systemic risks. In the known cases (e.g. in China, Korea, and Romania), the regulatory authorities deemed this step a success, although usually this was introduced as part of a bigger package, thus its individual effect is hard to assess (Borio et al. 2007). In the Hungarian literature, we can also find papers which dealt with the regulation of PTI. After analysing the mortgage loan portfolio, Berlinger - Walter (2013) describe "repayment burden" - that is PTI - as the most important systemic risk factor. They also analyse the different economic factors affecting PTI (net income, exchange rate, interest rate). In their income contingent repayment proposal, the main objective is to reduce this "repayment burden" significantly and to ease systemic risk.

Therefore, it is important to examine the relationship between a loan's longterm PD and the borrowing household's PTI, and to identify the PTI values which mark excessive risk-taking in the case of a loan. Based on our model estimates, we attempted to clarify this issue with the help of the data and methodology 


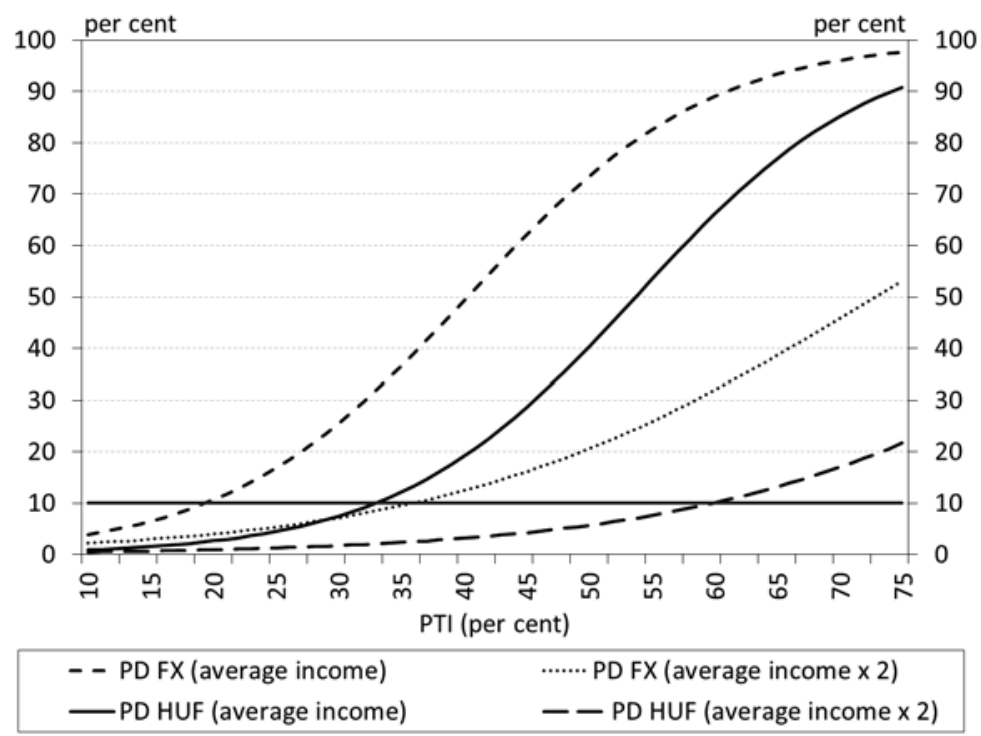

Chart 2. Long-term PD in the function of the PTI with different denominations and income Source: The survey.

available to us. ${ }^{7}$ We calculated developments in a household's long-term PD in function of the PTI in the case of a foreign currency loan and in the case of a HUF-denominated loan. For the purposes of this exercise, we used a representative household that could be considered, based on the sample and other information, to be average. The household was average in terms of the other variables of the model: it consisted of four members with two wage earners; their income was the same as the net average income of the national economy. The household's payment-to-income ratio for other loans was $6 \%$ and it spent $75 \%$ of its total income on consumption. With a probability of $22 \%$ for HUF loans and $32 \%$ for FX loans, their loan was intermediated. Per capita instalment amount can be derived from the different PTI values.

The values thus received are shown in Chart 2. The question arises as to what exactly is the long-term PD level that does not point to excessive risk-taking

7 We must note, however, that there is a difference between the PTI prescribed by the authorities and the PTI used in our model: the regulation always pertains to the initial PTI at the time of loan disbursement, while in our estimate, we used the household's actual PTI as at the time of the survey (as this was the only information we had). There may be a considerable difference between the two due to changes in the exchange rate, interest rate, and income. In our opinion, however, this does not have a material distorting effect on the results presented. 
(assuming the natural functioning of the banking system). In our sample, the total loan portfolio comprises 10 currently non-performing loans in the case of housing loans, while non-performing loans account for $17 \%$ of the portfolio in the case of home equity loans. This observation, however, pertains to a period that was characterised by higher than desirable lending risks and the excessive indebtedness of borrowers (which is reflected, even in our days, in soaring and historically high banking sector NPL rates and the payment burdens of foreign currency debtors). Thus, the desirable PD value is lower than this.

In order to determine this value more precisely, we performed a calculation based on simple rules of thumb. The high NPL rate (around 20\%) currently characterising mortgage loans was induced by high probabilities of default, the declining loan portfolio, and the low portfolio cleaning rates. From a simple calculation, we can deduce that, in the context of the assumptions of a normal business cycle, the current banking sector NPL ratio would be about $5-6 \%$ in the case of mortgage loans. For the purposes of the calculation, we considered a 10 -year period where the loan portfolio grows by $5.5 \%$ annually (corresponding to the rate of nominal GDP growth in case of $2.5 \%$ real growth and a $3 \%$ inflation rate), the probability of default (i.e. the customary PD) is $1.5 \%$ and the quarterly cleaning rate is $5 \%$. As a result of this calculation, the NPL ratio would be around $5.5 \%$ after 10 years, implying a risk of manageable size for the banking sector. This view is supported by several factors.

We have checked the household NPL ratio for the last few years in the other Visegrád countries, which were performing much better than Hungary. The average level was around 5.6\% (Chart 3). Note that the NPL ratio of state subsidised HUF mortgages was around $4.5-5 \%$ during the crisis, which confirms our view that this is a tolerable level. The faster growth of the loan stock or better cleaning activity may result in a lower ratio, but our goal was finding an acceptable maximum level.

It is due to the specificities of the sample that we could not consider cleaning, irrespective of how long the specific loan has been delinquent. Moreover, in our sample we could not reckon with a growth of the portfolio either. Considering all these factors, the tolerable NPL ratio would be about $10-11 \%$ within the portfolio (mainly due to the lack of cleaning). ${ }^{8}$ The latter shows how big the actual non-performance ratio would have been in our sample in the context of normal risk appetite and with all other conditions being unchanged. Since this is the realised value of the PD definition used for our estimate in the sample average, for the rest of our study we consider this $10 \%$ long-term PD to be the risk taking

8 Indeed, our sample implicitly assumes that there is no cleaning. 


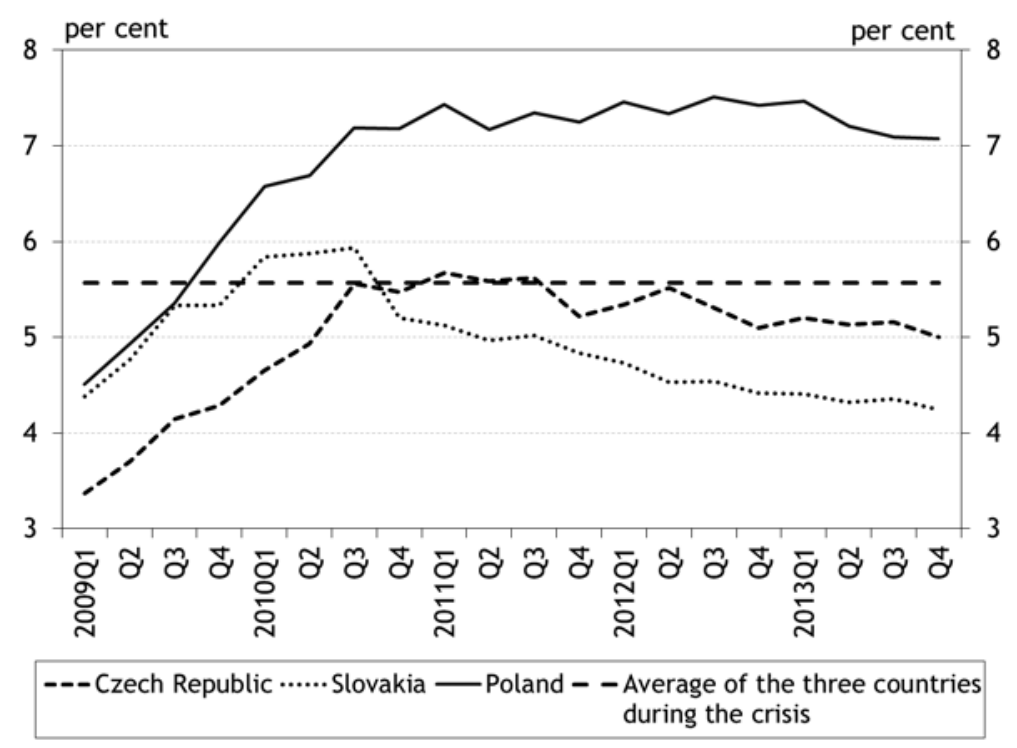

Chart 3. NPL ratio in the region during the crisis

Source: ECB.

that is still tolerable for the regulator (this $10 \%$ long-term PD level is highlighted in Chart 2).

When HUF- and FX-denominated loans are compared to one another, the two loan categories may be considered to have identical risk (in terms of non-performance) in the context of extremely different PTI values. In the case of HUF loans, a $38 \%$ PTI, while in the case of FX loans, a 24\% PTI is consistent with the aforementioned $10 \%$ long-term PD value. Therefore, during the review period, an average household's indebtedness in foreign currency increased long-term PD to a degree corresponding to a $14 \%$ increase in PTI. This difference can be considered significant even if we know that some of it can be explained by unilateral interest rate hike.

In addition to currency denomination, we also examined the relationship between the probability of default and the payment-to-income ratio in function of the household's income. As households' income increases, they typically spend less and less on consumption: while the consumption rate is often $100 \%$ in the case of low-income households, households with higher income can accumulate substantial savings. Thus, an increase in income also increases the PTI that can be tolerated by the household. Chart 2 indicates how long-term PD changes in function of the PTI if the household's income is twice the amount of the net average income. 
Table 6 sums up the PTI values belonging to the $10 \%$ long-term PD and various household income brackets. Accordingly, in the case of a household with a HUF loan and an average income, even a $20 \%$ higher PTI would not imply excessive indebtedness if the household's income was doubled. While in the case of foreign currency loans this value is smaller - $10 \%-$, it can still be considered high.

Our sample is heterogeneous on the start of the contract (and for this reason, on macroeconomic and regulatory conditions as well); we have made these calculations for the period of 2004-2008 (among the robustness tests we have shown this model as well and it could be also seen that the two models were very similar). Table 7 summarises the results. Comparing these numbers with the results in $\mathrm{Ta}$ ble 6, it is clear that there is no significant difference in the case of FX loans. Regarding HUF loans, we got higher PTIs for the shorter sample by 7-9 percentage points. Since most of the FX loans (83\%) were issued in the period 2004-2008, getting similar results for the two models is not surprising. In the case of HUF loans, only $36 \%$ of the sample was in the shorter period, so we lose a lot of information on them in this model. In the case of HUF loans, we think that the model gives better results on the whole sample.

\section{Table 6}

PTI values belonging to the $10 \%$ long-term PD of an average household in the context of different incomes and denominations (total loans)

\begin{tabular}{|l|c|c|c|c|c|}
\hline per cent & 100,000 HUF & 150,000 HUF & 200,000 HUF & 250,000 HUF & 300,000 HUF \\
\hline HUF & 34 & 38 & 42 & 49 & 59 \\
\hline FX & 22 & 24 & 26 & 30 & 35 \\
\hline
\end{tabular}

Source: The survey.

\section{Table 7}

PTI values belonging to the $10 \%$ long-term PD of an average household in the context of different incomes and denominations (2004-2008)

\begin{tabular}{|l|c|c|c|c|c|}
\hline per cent & $100,000 \mathrm{HUF}$ & $150,000 \mathrm{HUF}$ & $200,000 \mathrm{HUF}$ & $250,000 \mathrm{HUF}$ & $300,000 \mathrm{HUF}$ \\
\hline HUF & 41 & 45 & 51 & 58 & 69 \\
\hline FX & 22 & 24 & 26 & 30 & 35 \\
\hline
\end{tabular}

Source: The survey.

Our results carry an important message from a regulatory perspective: prescribing the same PTI for HUF and FX loans may be unnecessarily restrictive for the former, and excessively permissive for the latter. A similar conclusion can be drawn about the uniform regulations pertaining to households in different income brackets. It would be therefore reasonable to introduce a distinction and 
apply different PTI limits for different denominations and income levels. Obviously, the values indicated above imply desirable average levels over the long term. When the economy and the credit market show signs of overheating, there is a higher risk of overly permissive regulations, while during a recession and in the context of a credit crunch, the risk of excessively stringent PTI regulations is higher. Accordingly, the regulator should also consider developments in the economic and lending cycle, and also the interest rate dynamics.

\section{CONCLUSIONS}

We estimated the probability of default of Hungarian households with the help of a representative questionnaire-based survey. The data structure enabled us to use cross-sectional, binary choice models. We used the survey question pertaining to repayment delinquency as our response variable and considered the specific loan non-performing if the instalment was 90 days past due. In the model received as the final specification, the signs and magnitude of the variables were consistent with economic intuitions. The results proved to be robust to model specification, i.e., whether to include vintage effects and non-linearity.

Of the features that purely characterise households, only one variable proved to be significant: the "ratio of income earners to total household members", which captures the household's labour market activity and its composition according to income position. According to the estimate, more income earners within the same household reduce the probability of default proportionately.

As regards the features of the loan, two variables proved to be significant in the estimate. Firstly, foreign currency loans are riskier than HUF loans, secondly, compared to directly disbursed bank loans, the default probability of loans via agents is higher.

As regards the rest of the indicators, four factors proved to have significant explanatory power. The PTI level measures the burden incurred by the household in repaying the loan amount, the level of indebtedness. The higher a household's indebtedness in proportion to its income (PTI), the higher the long-term PD of its loan. According to the estimate, the risk associated with a loan will be also greater if the household has debt service on other loans as well. This effect is captured by the variable "payment-to-income ratio for other loans". The ability to repay is not only influenced by instalments. Households with a higher level of "expenditures above the instalment amount" also face a higher probability of default. Finally, "per capita instalment amount" proved to be significant as well; however, the sign of the variable is negative. This means that a higher instalment amount induces lower long-term PD. Instead of indebtedness, this variable 
primarily captures income position and, in line with this, instead of the instalment amount it measures the instalment amount that a household is capable of paying. In consideration of this, the negative sign of the partial effect is understandable.

During our estimates, we have also tested several variables which were not included in the final model (due to their insignificant effect), even though they may have considerable explanatory power based on empirical experiences. We demonstrated, however, that the effects reflected in them are captured by other indicators that proved to be significant in our model. For instance, distinguishing on the basis of loan purpose, we can establish that home equity loans perform worse than housing loans. This, however, is due to the fact that households with home equity loans are more indebted with worse income and labour market positions. The situation is similar when we compare loans disbursed in the periods of 2004-2006 and 2007-2008: debtors' higher indebtedness explains the higher non-performance rate of loans disbursed during the latter period.

Based on the model estimated, we examined the relationship between PTI and the probability of default in the case of different loan denominations and different household incomes. The results carry two important messages from a regulatory perspective. Prescribing the same PTI for HUF and FX loans may be unnecessarily restrictive for the former, and excessively permissive for the latter. Similarly, the uniform regulation of households with different income levels may also lead to undesired anomalies. In order to avoid this, a potential new PTI regulation should differentiate between loans based on denomination and between households based on income levels.

\section{REFERENCES}

Balás, T. - Banai, Á. - Hosszú, Zs. (2015): A nemteljesítési valószínűség és az optimális PTIszint modellezése egy háztartási kérdőíves felmérés felhasználásával (Modelling Probability of Default and Optimal PTI Level by Using a Household Survey). MNB Occasional Papers, No. 117.

Banai, Á. - Hosszú, Zs. - Körmendi, Gy. - Sóvágó, S. - Szegedi, R. (2013): Stress Testing at the Magyar Nemzeti Bank. MNB Occasional Papers, No. 109.

Basso, H.S. - Calvo-Gonzalez, O. - Jurgilas, M. (2007): Financial Dollarization - The Role of Banks and Interest Rates. Working Paper Series, 748, European Central Bank.

Berlinger, E. - Walter, Gy. (2013): Unortodox javaslat a devizahitelek rendezésére (Unorthodox Suggestion for Solving the FX Loan Problem). Hitelintézeti Szemle, 12(6): 469-494.

Bethlendi, A. (2011): Policy Measures and Failures on Foreign Currency Household Lending in Central and Eastern Europe. Acta Oeconomica, 61(2): 193-223.

Blanco, R. - Gimeno, R. (2012): Determinants of Default Ratios in the Segment of Loans to Households in Spain. Banco de Espańa Working Papers, 1210.

Borio, C.E.V. - Shim, I. (2007): What can (Macro-)Prudential Policy do to Support Monetary Policy? BIS Working Papers, No. 242. 
Gáspár, K. - Varga, Zs. (2011): A bajban lévő lakáshitelesek elemzése mikroszimulációs modellezéssel (Analysis of Mortgage Borrowers in Distress, Using Micro-Simulation Modelling). Közgazdasági Szemle, LVIII June: 529-542.

Holló, D. (2009): Risk Developments on the Retail Mortgage Loan Market. MNB Bulletin, October: $13-18$.

Holló, D. - Papp, M. (2007): Assessing Household Credit Risk: Evidence from a Household Survey. MNB Occasional Papers, No. 70.

Hosszú, Zs. (2011): Pre-Crisis Household Consumption Behaviour and Its Heterogeneity according to Income, on the Basis of Micro Statistics. MNB Bulletin, October: 28-35.

Hudecz, A. (2013): Parallel Stories: FX Lending to Households in Poland, Romania and Hungary, 1997-2011. Acta Oeconomica, 63(3): 257-286.

Király, J. - Banai, Á. (2012): A „flow” és a „stock” árnyalatai (gazdasági esszé a devizahitelezés kapcsán) (Shades of 'Flow' and 'Stock' [Economic Essay on Foreign Currency Lending]). In: Muraközy, L. (ed.): Feldobott kö? Tények és tendenciák a 21. században (A Stone Cast? Facts and Trends in the 21st Century). Budapest: Akadémiai Kiadó.

La Cava, G. - Simon, J. (2003): A Tale of Two Surveys: Household Debt and Financial Constraints in Australia. Research Discussion Paper, No. 08-2003. Reserve Bank of Australia.

Lydon, R. - McCarthy, Y. (2013): What Lies Beneath? Understanding Recent Trends in Irish Mortgage Arrears. The Economic and Social Review, Economic and Social Studies, 44(1): 117-150.

Magyar Nemzeti Bank (MNB) (2011): Report on Financial Stability. November.

May, O. - Tudela, M. (2005): When is Mortgage Indebtedness a Financial Burden to British Households? A Dynamic Probit Approach. Working Paper, No. 277/2005, Bank of England.

Mian, A, - Sufi, A. (2011): House Prices, Home Equity-Based Borrowing, and the US Household Leverage Crisis. American Economic Review, American Economic Association, 101(5): 2132-2256.

Zettelmeyer, J. - Nagy, P.M. - Jeffrey, S. (2010): Addressing Private Sector Currency Mismatches in Emerging Europe. EBRD Working Paper, No. 115. 